\title{
Correction to: The novel compound PBT434 prevents iron mediated neurodegeneration and alpha-synuclein toxicity in multiple models of Parkinson's disease
}

David I. Finkelstein ${ }^{1 *}\left(\mathbb{0}\right.$, Jessica L. Billings ${ }^{1}$, Paul A. Adlard ${ }^{1}$, Scott Ayton ${ }^{1}$, Amelia Sedjahtera ${ }^{1}$, Colin L. Masters ${ }^{1}$, Simon Wilkins', David M. Shackleford ${ }^{3}$, Susan A. Charman³, Wojciech Bal ${ }^{4}$, Izabela A. Zawisza ${ }^{4}$, Ewa Kurowska ${ }^{4}$,

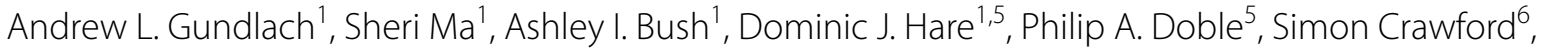
Elisabeth C. L. Gautier², Jack Parsons², Penny Huggins ${ }^{2}$, Kevin J. Barnham ${ }^{1,7}$ and Robert A. Cherny ${ }^{1,2^{*}}$

\section{Correction to: Acta Neuropathologica Communications (2017) 5:53 https://doi.org/10.1186/s40478-017-0456-2}

Following publication of the original article [1], the author identified an error in Fig. 4E. The data and statistics were correct, but the synaptophysin blot was incorrect.

The incorrect (Fig. 1) and correct figure (Fig. 2) are shown in this correction article.
The original article can be found online at https://doi.org/10.1186/s40478017-0456-2.

*Correspondence: d.finkelstein@florey.edu.au; rcherny@unimelb.edu.au ${ }^{1}$ The Florey Institute of Neuroscience and Mental Health, The University of Melbourne, Melbourne, VIC 3010, Australia

Full list of author information is available at the end of the article

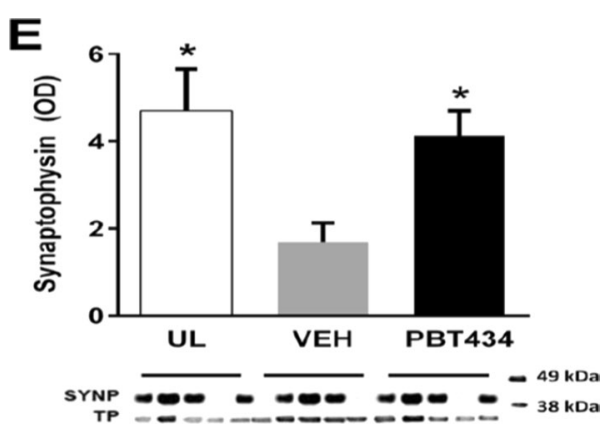

Fig. 1 Incorrect version of Fig. 4E as originally published

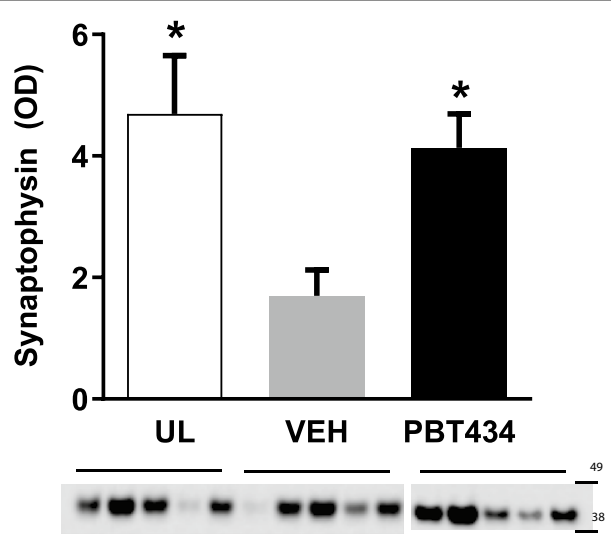

Fig. 2 Correct version of Fig. 4E permits use, sharing, adaptation, distribution and reproduction in any medium or format, as long as you give appropriate credit to the original author(s) and the source, provide a link to the Creative Commons licence, and indicate if changes were made. The images or other third party material in this article are included in the article's Creative Commons licence, unless indicated otherwise in a credit line to the material. If material is not included in the article's Creative Commons licence and your intended use is not permitted by statutory regulation or exceeds the permitted use, you will need to obtain permission directly from the copyright holder. To view a copy of this licence, visit http://creativecommons.org/licenses/by/4.0/. The Creative Commons Public Domain Dedication waiver (http://creativeco mmons.org/publicdomain/zero/1.0/) applies to the data made available in this article, unless otherwise stated in a credit line to the data. 


\section{Author details}

${ }^{1}$ The Florey Institute of Neuroscience and Mental Health, The University of Melbourne, Melbourne, VIC 3010, Australia. ${ }^{2}$ Prana Biotechnology Ltd, Parkville, VIC 3052, Australia. ${ }^{3}$ Centre for Drug Candidate Optimisation, Monash Institute of Pharmaceutical Sciences, Monash University, Parkville, VIC 3052, Australia. ${ }^{4}$ The Institute of Biochemistry and Biophysics, Polish Academy of Sciences, Warsaw, Poland. ${ }^{5}$ Elemental Bio-Imaging Facility, The University of Technology Sydney, Broadway, Ultimo, NSW 2007, Australia. ${ }^{6}$ Australia Electron Microscope Unit, School of Biosciences, The University of Melbourne, Melbourne, VIC 3010, Australia. ${ }^{7}$ Bio21 Institute and Department of Pharmacology and Therapeutics, The University of Melbourne, Melbourne, VIC 3010, Australia.

Published online: 29 September 2021

\section{Reference}

1. Finkelstein DI, Billings JL, Adlard PA et al (2017) The novel compound PBT434 prevents iron mediated neurodegeneration and alpha-synuclein toxicity in multiple models of Parkinson's disease. Acta Neuropathol Commun 5:53. https://doi.org/10.1186/s40478-017-0456-2

\section{Publisher's Note}

Springer Nature remains neutral with regard to jurisdictional claims in published maps and institutional affiliations.
Ready to submit your research? Choose BMC and benefit from:

- fast, convenient online submission

- thorough peer review by experienced researchers in your field

- rapid publication on acceptance

- support for research data, including large and complex data types

- gold Open Access which fosters wider collaboration and increased citations

- maximum visibility for your research: over $100 \mathrm{M}$ website views per year

At BMC, research is always in progress.

Learn more biomedcentral.com/submissions 